\title{
The Role of Individual and Neighborhood Characteristics on Mental Health after a Period of Economic Crisis in the Lisbon Region (Portugal): A Multilevel Analysis
}

\author{
Adriana Loureiro ${ }^{1, *(1)}$, Paula Santana ${ }^{2}$, Carla Nunes ${ }^{3}$ and Ricardo Almendra ${ }^{1} \mathbb{(}$ \\ 1 Centre of Studies on Geography and Spatial Planning (CEGOT), Faculty of Arts and Humanities, Colégio de \\ São Jerónimo, University of Coimbra, 3004-530 Coimbra, Portugal \\ 2 Centre of Studies on Geography and Spatial Planning (CEGOT) and Department of Geography and Tourism, \\ Faculty of Arts and Humanities, Colégio de São Jerónimo, University of Coimbra, 3004-530 Coimbra, \\ Portugal \\ 3 Centre for Research in Public Health and National School of Public Health, Nova University of Lisbon, \\ Avenida Padre Cruz, 1600-560 Lisbon, Portugal \\ * Correspondence: adrianalour@gmail.com; Tel.: +351-239851349
}

Received: 27 March 2019; Accepted: 21 July 2019; Published: 24 July 2019

\begin{abstract}
Mental health is an intrinsic dimension of health influenced by individual and contextual factors. This cross-sectional study analyzes the association between the individual, neighborhood characteristics, and one's self-assessed mental health status in the Lisbon region after an economic crisis. Via the application of multilevel regression models, the study assesses the link between one's neighborhood environment-deprivation, low self-assessed social capital, and low self-assessed satisfaction with the area of residence-and mental health regardless of one's individual characteristics. Constraints related to the economic crisis play an important role in the explanation of poor mental health.
\end{abstract}

Keywords: mental health; mental health determinants; neighborhood environment; economic crisis; Portugal

\section{Introduction}

Mental disorders are one of the world's leading causes of disability, morbidity, and mortality [1], namely premature deaths. Between 2007 and 2017, the years of life lost by mental disorders globally increased by $18.5 \%$ [2]. In 2015, depression was the major contributor to suicide deaths and the highest contributor to global disability ( $7.5 \%$ of all years lived with disability); anxiety disorders were ranked sixth $(3.4 \%)$ [1].

The definition of mental health, according to the World Health Organization [3], goes beyond the absence of mental disorder to include the concepts of subjective well-being, perceived self-effectiveness, self-determination, autonomy, social competence, inter-generational dependency, and self-realization of one's intellectual and emotional potential. The same organization in 2007 [4] noted that mental health is "a state of well-being in which the individual realizes his or her own abilities, can cope with the normal stresses of life, can work productively and fruitfully, and is able to make a contribution to his or her community". Furthermore, mental health is influenced by the interaction of a set of genetic, biological, psychological, social, and contextual factors [5].

Recent scientific evidence, focused on multifactorial research, suggests that aspects related to an individual's neighborhood environment (one's place of residence) may influence a person's mental health, regardless of, or beyond, his/her individual characteristics [6-17]. 
Neighborhood environment is understood within a holistic perspective, which integrates the complex interrelationship of multiple contextual factors that ascribe a particular value to each place [18-20]. Socio-environmental characteristics of the neighborhoods where people are born, grow up, live, work, and age may produce positive or negative impacts on both individual and collective health (including mental health), acting as one of its determinants [21-26]. Places, as dynamic organisms, consisting of a set of multiple and overlapping neighborhood environments and densities, can promote exposures and generate diverse vulnerabilities related to built, connective, or relational space, which negatively influence human health, particularly mental health [27].

Through this approach, several authors suggested that improving one's living environmental conditions (contextual characteristics) is fundamental to improving the mental health of the population, by taking actions on factors such as poverty [28], deprivation [11], income [13], employment/unemployment [11,29], natural environment [30,31], built environment [12,32,33], housing [34], social networks [35], social capital [12,35], social cohesion [15], and social discrimination and security [36].

Furthermore, certain phenomena leave their mark on the environment and may lead to the transformation and adaptation of the communities, as in the cases of economic and financial crises $[37,38]$, rapid and uncontrolled urbanization [39,40], and high unemployment rates [41,42]. These phenomena are powerful drivers of health, particularly the financial and economic crises and their impacts, as they are often associated with an increase in mental health problems [43,44], namely mental disorders [43,45], admissions to mental health facilities [43], and suicide [43,45,46]. The health impacts of an economic crisis are often uneven with certain individuals or groups of individuals being more affected than others by downward cycles in the economy. Vulnerable groups (e.g., single-parent families, individuals of lower socio-economic status, ethnic minorities, migrants, the elderly) tend to be less resilient to negative economic conditions and to report more severe mental health problems as a consequence of the effects of the economic and financial constraints on their environment [38,43-45].

As for Portugal, its social and economic structures were indeed impacted by the effects of the "Great Recession", which, according to the technical definition of an economic recession (two quarters of negative growth), lasted from 2009-2011 [47]. This compelled the country to appeal for international financial support, which resulted in the program for economic adjustment applied from 2011-2014 under the directives of the International Monetary Fund, the European Central Bank, and the European Commission. This was an austerity period characterized by, on the one hand, severe cuts in public spending and, on the other hand, a tight control of public expenditure, with repercussions on: (i) unemployment: increasing from 8.8\% in 2008 to 15.8\% in 2012 [47]; (ii) emigration: 136,615 new emigrants registered between 2009 and 2012 [48]; and (iii) purchasing power: standards for European Union countries decreased from $81 \%$ in 2009 to $77.3 \%$ in 2013 [49].

As far as the authors know, there is still limited scientific evidence about the effect of contextual and individual factors on mental health in Portugal. Thus, the objective of this work is to analyze the association between the individual and neighborhood characteristics and the self-assessed mental health status in four municipalities of the Lisbon region (Portugal) following a period of economic crisis.

\section{Materials and Methods}

\subsection{Study Area}

The study area of this research is located within Lisbon region (according to NUT 3 (Nomenclature of Territorial Units for Statistics, Level 3) in 2011). Four municipalities were selected for their distinct geographical and socioeconomic characteristics and included consolidated urban areas (Lisbon), recent urban growth areas characterized by higher (Amadora) and lower (Oeiras) levels of deprivation and rural areas (Mafra). The four municipalities were studied at the level of civil parishes of 2011 (91 parishes) (Figure 1), the lowest local level of Portuguese administrative division. The parish scale was selected to represent and analyze the neighborhood level, in accordance with previous studies [50]. 

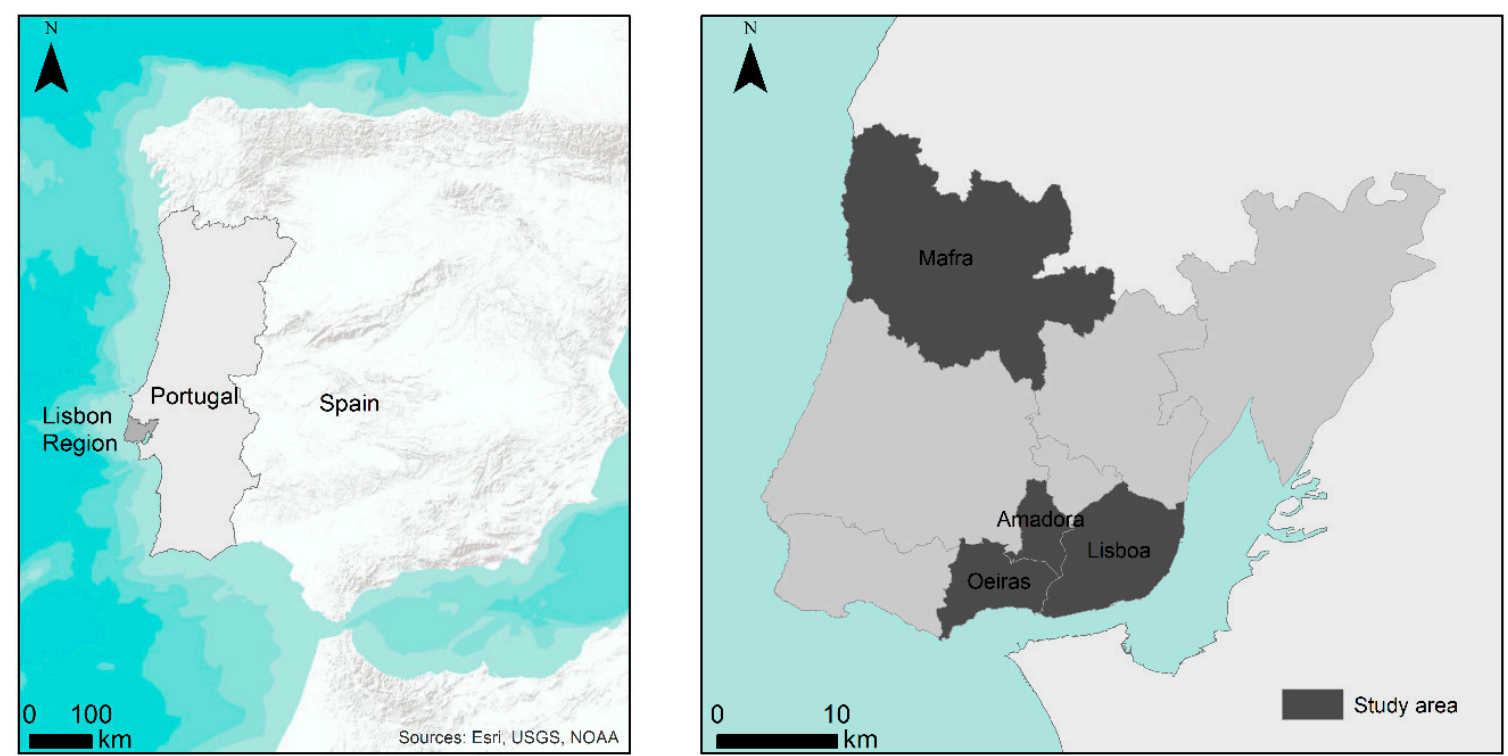

Figure 1. Location of study area.

The study area had 971,674 inhabitants in 2011 (average population by parish was 8880 inhabitants, ranging between 320 and 42,306), according to the Census 2011 of Statistics Portugal [51], of which 54\% were women and $46 \%$ were men. About $21 \%$ of this population was over age 65 , corresponding to $61 \%$ women and 31\% men. Population density varied between 75 and 19,104 inhabitants per square kilometer, with an average of 5265 inhabitants per square kilometer [48].

\subsection{Data Collection}

The primary source of information used was the questionnaire applied, between August 2014 and February of 2015, to the adult population living in the four municipalities. The survey collected information to support the assessment of the relationship between the individual and neighborhood characteristics and the self-assessed mental health status after the economic crisis (Great Recession). According to Stuckler et al. [52], the health outcomes (epidemiological data) have, normally, a latency period between two and five years; therefore, the impacts of the Great Recession on the health of the Portuguese population are still ongoing [53].

Eligibility criteria for participants in the questionnaire were: (a) being over 17 years of age at the time of the survey; (b) living in one of the selected municipalities. The Research Ethics Board at "Centro Hospitalar Lisboa Ocidental" (Hospital of Metropolitan Area of Lisbon, Portugal) provided ethics approval for this study, integrated in the research project SMAILE, Mental Health-Evaluation of the Local and Economic Determinants.

Data were collected through a representative random sample (by quota according to sex and age by municipality) of 1066 resident individuals, with a sampling error of $6 \%$ and a confidence interval of $95 \%$. The individuals were randomly selected on the street, and data were obtained from in-person interviews conducted by trained interviewers. The response rate was $79 \%$. Table 1 describes some characteristics of the study participants. 
Table 1. Description of the study participants.

\begin{tabular}{|c|c|c|c|}
\hline Variables & Categories & $N$ & $\%$ \\
\hline \multirow{2}{*}{ Gender } & Female & 573 & $53.8 \%$ \\
\hline & Male & 493 & $46.2 \%$ \\
\hline \multirow{5}{*}{ Age group } & $18-29$ & 172 & $16.1 \%$ \\
\hline & $30-44$ & 319 & $29.9 \%$ \\
\hline & $45-59$ & 246 & $23.1 \%$ \\
\hline & $60-74$ & 202 & $19.0 \%$ \\
\hline & $\geq 75$ & 127 & $11.9 \%$ \\
\hline \multirow{2}{*}{ Mental health } & Good mental health $($ score $>50$ ) & 715 & $67.1 \%$ \\
\hline & Poor mental health (score $\leq 50$ ) & 351 & $32.9 \%$ \\
\hline \multirow{2}{*}{ Educational level } & $\leq 12$ years & 770 & $72.2 \%$ \\
\hline & $>12$ years & 296 & $27.8 \%$ \\
\hline \multirow{2}{*}{ Physical activity } & Yes & 525 & $49.2 \%$ \\
\hline & No & 541 & $50.8 \%$ \\
\hline \multirow{3}{*}{ Hypertension } & Yes & 300 & $28.2 \%$ \\
\hline & No & 756 & $70.9 \%$ \\
\hline & Missing data & 10 & $0.9 \%$ \\
\hline \multirow{3}{*}{ Smoking habits } & Yes & 275 & $25.8 \%$ \\
\hline & No & 775 & $72.7 \%$ \\
\hline & Missing & 16 & $1.5 \%$ \\
\hline \multirow{4}{*}{$\begin{array}{l}\text { Financial situation of the } \\
\text { household }\end{array}$} & Able to save money & 533 & $50.0 \%$ \\
\hline & Able to pay current expenses only & 377 & $35.4 \%$ \\
\hline & Difficulty paying current expenses & 146 & $13.7 \%$ \\
\hline & Missing & 10 & $0.9 \%$ \\
\hline \multirow{2}{*}{$\begin{array}{c}\text { Concerns with meeting } \\
\text { daily expenses }\end{array}$} & More than two years ago & 676 & $63.4 \%$ \\
\hline & Less than two years ago & 390 & $36.6 \%$ \\
\hline \multirow{3}{*}{$\begin{array}{l}\text { Main expenses burdening } \\
\text { household budget }\end{array}$} & Household budget mostly allocated to health & 194 & $18.2 \%$ \\
\hline & $\begin{array}{c}\text { Household budget mostly allocated to other } \\
\text { expenses (e.g., food, education, } \\
\text { housing, transport) }\end{array}$ & 863 & $81.0 \%$ \\
\hline & Missing & 9 & $0.8 \%$ \\
\hline \multirow{3}{*}{$\begin{array}{l}\text { Unemployed person in } \\
\text { the family }\end{array}$} & Yes & 430 & $40.4 \%$ \\
\hline & No & 624 & $58.5 \%$ \\
\hline & Missing & 12 & $1.1 \%$ \\
\hline
\end{tabular}

Individual data were collected on: (a) biological and socioeconomic characteristics, (b) behavioral characteristics and health status, (c) perception of neighborhood characteristics, (d) economic-financial constraints, and (e) mental health status.

At the ecological level, secondary data on neighborhood characteristics (material deprivation and population density) were calculated based on data provided by Statistics Portugal [51]. 


\subsection{Outcome}

Self-assessed mental health $(\mathrm{MH})$ was measured through the mental health and vitality scales on the version validated for the Portuguese population of the Short Form 36-item Health (SF-36v2) [54]. The SF-36 is a generic health survey, which measures and assesses population health status and health-related quality of life from the individual's point of view [55]. The mental health and vitality scales were computed following the methodology proposed by Ware et al. [56] and range from 0-100, corresponding to the situations in which the individual experiences total and no disability, respectively. The MH was converted into a dichotomous variable where scores lower or equal to 50 represent poor mental health and scores higher than 50 mean good mental health [55].

\subsection{Neighborhood Characteristics}

To analyze the neighborhood characteristics of the area of residence (parishes) that could be associated with $\mathrm{MH}$, the population density (individuals per square kilometer) and a deprivation index (DI), both for 2011, were used. Population density was normalized through the z-score method. The DI was constructed with the following indicators: (a) illiteracy rate (\% of people over 10 years of age unable to read or write), (b) unemployment rate (\% of unemployed among the active population) and (c) substandard housing rate (\% of houses without a toilet) collected in the Portuguese Statistics [51]. Other studies assessing the relationship between environmental characteristics and health also built multidimensional composite indexes to summarize neighborhood conditions [46,57-59]. The composite index was constructed based on the Carstairs and Morris method [60], which provides a sum of the standardized values of the indicators (using the z-score method, which applies to each indicator a weighted mean of zero and a variance of one, with the same influence on the final result). Higher index values reflect higher deprivation, and zero represents the average of all parishes in the study area. The DI was categorized into terciles (T1, T2, T3).

\subsection{Perception of Neighborhood Characteristics}

Using the individual information collected via a questionnaire on the self-assessment of one's area of residence, two contextual scores were constructed: (a) score of satisfaction with one's area of residence and (b) score of neighborhood's social capital.

The first was based on the individuals' responses to 15 questions on environmental quality, employment, and the facilities and services on offer (see Appendix A, Table A1). For each question, the response reflects qualitatively the level of satisfaction by linear gradation: from total dissatisfaction (0) to maximum satisfaction (100). The response options were converted into a quantitative scale (with intervals assuming the same gap). The score of satisfaction with the area of residence was computed through the arithmetic mean of the scores of the 15 questions.

The score of neighborhood social capital was based on Putnam's [61] definition of social capital—linking, bonding and bridging social capital—assessing the sense of belonging and identity, family and community relational support, isolation, and trust in public institutions (see Appendix A, Table A2); Nogueira [62] used a similar approach to assess the neighborhood social capital in the Lisbon Metropolitan Area. The final scores resulting from the arithmetic mean of the score of the individual questions (calculated via the same method) were used to construct the respondents' score of satisfaction with the area of residence.

The scores of satisfaction with the area of residence and of neighborhood social capital were categorized into a binary variable where scores lower or equal to 50 represent less satisfaction with the area of residence and lower neighborhood social capital, respectively.

\subsection{Biological, Socioeconomic, Behavioral Characteristics, and Health Status}

The association between biological and socioeconomic characteristics and $\mathrm{MH}$ were examined in terms of age, gender, and education level. Education level was used to represent socioeconomic 
characteristics. Evidence in the literature shows that educational level is one of the strongest social determinants of health, indicated as a major predictor of mortality, morbidity, health behaviors, and health literacy [63-66]. This variable was clustered into two classes: individuals having 12 or less and those with 12 years of education or more (as stipulated by Decree-Law 176/2012 dated 2 August, 12 years of compulsory education are established in Portugal). The consequences of individual behaviors on $\mathrm{MH}$ were assessed through the physical activity (regular physical activity: yes or no) and smoking habits (regular smoker: yes or no). The respondent's health status was analyzed by determining whether the hypertensive status reported by the individual had been diagnosed by a doctor (yes or no).

\subsection{Economic and Financial Constraints}

The statistical relationship between economic and financial constraints and MH was analyzed by: (a) financial situation (financial situation of the household: able to save money, able to pay current expenses only, or difficulty paying expenses); (b) concerns with meeting daily expenses (more than two years ago or less than two years ago); (c) the main expenses burdening household budget (household budget mostly allocated to: health, food, education, housing, or transport); and (d) unemployed persons in the family (yes or no).

\subsection{Statistical Analysis}

To address the association between the individual and neighborhood characteristics and $\mathrm{MH}$, a multilevel binary logistic regression was applied. This method allows for a 2-level structure, with individuals nested in neighborhoods; previous research already used this approach to account for the lack of spatial independence $[11,13,25,67,68]$. The odds ratios (ORs) of having poor $\mathrm{MH}$ and respective $95 \%$ confidence intervals (CIs) were calculated.

Mental health status (outcome) was initially modelled by the contextual characteristics (Model 0 ). Furthermore, a step-entry method was applied building on Model 0: Model 1 includes the perception of context characteristics; Model 2 adds to Model 1 by including biological, socioeconomic, and behavioral characteristics and health status information; and Model 3 builds on Model 2 by adjusting for economic and financial constraints. The step-entry sequence allowed understanding the statistical effect of adjusting for individual level risks on neighborhood level factors, along with further wider macroeconomic factors; this rationale followed the work of Chum and O'Campo [67]. During the sensitivity analysis process, the classification of the variables to be included in the models was tested (e.g., the use of tertiles), and the statistical criterion was followed; consequently, the classification that better fit the models was adopted. Furthermore, statistical interactions between variables were also tested, but the validation measures of the models did not suggest its inclusion.

Possible multicollinearity between the independent variables was assessed through a correlation matrix. The multilevel binary logistic regression was performed using SPSS Version 22 (IBM Corp., Armonk, NY, USA).

\section{Results}

Model 0 assesses the association between MH and contextual characteristics. It was found that individuals living in less deprived parishes (T1 and T2) had a significantly lower probability of having poor $\mathrm{MH}$ than those living in more deprived neighborhoods (OR: T1 vs. T3 $=0.71, p<0.05$; OR: T2 vs. $\mathrm{T} 3=0.72, p<0.05)$ (Table 2). Population density was not significantly associated with one's MH status. 
Table 2. Multilevel binary logistic regressions of mental health (outcome). T, tercile.

\begin{tabular}{|c|c|c|c|c|c|}
\hline & $\begin{array}{l}\text { al Health: Odds Ratio }(95 \% \text { CI }) \\
\text { Total }(n=1.066)\end{array}$ & Model 0 & Model 1 & Model 2 & Model 3 \\
\hline \multirow{3}{*}{ Neighborhood characteristics } & $\begin{array}{l}\text { Deprivation } \\
\text { T1 (low) vs. T3 a (high) }\end{array}$ & $0.71 *(0.51-0.99)$ & $0.79(0.56-1.01)$ & $0.81(0.55-1.20)$ & $0.80(0.53-1.19)$ \\
\hline & $\mathrm{T} 2$ vs. $\mathrm{T}^{\mathrm{a}}$ & $0.72 *(0.52-0.98)$ & $0.68 *(0.49-0.94)$ & $0.65 *(0.46-0.93)$ & $0.65 *(0.45-0.95)$ \\
\hline & Population density & $1.01(0.88-1.16)$ & $0.95(0.83-1.10)$ & $0.95(0.81-1.11)$ & $0.91(0.77-1.07)$ \\
\hline \multirow{2}{*}{$\begin{array}{l}\text { Perception of } \\
\text { neighborhood characteristics }\end{array}$} & $\begin{array}{l}\text { Score of neighborhood social capital } \\
\text { Low vs. high }{ }^{\text {a }}\end{array}$ & - & $2.09^{* * *}(1.41-3.10)$ & $2.21 * * *(1.46-3.34)$ & $2.07^{* *}(1.33-3.23)$ \\
\hline & $\begin{array}{l}\text { Score of satisfaction with area of residence } \\
\text { Low vs. high }{ }^{\text {a }}\end{array}$ & - & $2.08^{* * *}(1.58-2.72)$ & $1.85^{* * *}(1.39-.46)$ & $1.76^{* * *}(1.31-2.40)$ \\
\hline \multirow{6}{*}{$\begin{array}{l}\text { Biological, socioeconomic, } \\
\text { behavioral, and characteristics and } \\
\text { health status }\end{array}$} & Age & - & - & $1.01(1.00-1.02)$ & $1.01(1.00-1.02)$ \\
\hline & $\begin{array}{l}\text { Sex } \\
\text { Female vs. male }{ }^{\text {a }}\end{array}$ & - & - & $2.29^{* * *}(1.72-3.06)$ & $2.19^{* * *}(1.61-2.97)$ \\
\hline & $\begin{array}{l}\text { Education } \\
\leq 12 \text { vs. }>12\end{array}$ & - & - & $1.10(0.77-1.59)$ & $0.900 .61-1.33)$ \\
\hline & $\begin{array}{l}\text { Physical activity } \\
\text { Inactivity vs. activity a }\end{array}$ & - & - & $1.50 * *(1.13-1.99)$ & $1.41 *(1.05-1.91)$ \\
\hline & $\begin{array}{l}\text { Hypertension } \\
\text { Yes vs. no }^{\text {a }}\end{array}$ & - & - & $1.50 *(1.08-2.10)$ & $1.40(0.98-1.99)$ \\
\hline & $\begin{array}{l}\text { Smoking habits } \\
\text { Yes vs. no a }\end{array}$ & - & - & $1.00(0.71-1.41)$ & $0.88(0.61-1.26)$ \\
\hline \multirow{5}{*}{ Economic and financial constraints } & $\begin{array}{l}\text { Household financial situation } \\
\text { Difficulty paying expenses vs. Able to save money }{ }^{\text {a }}\end{array}$ & - & - & - & $1.93^{* *}(1.22-3.05)$ \\
\hline & Able to pay current expenses only vs. able to save money ${ }^{a}$ & - & - & - & $1.75^{* *}(1.25-2.44)$ \\
\hline & $\begin{array}{l}\text { Concerns with meeting daily expenses } \\
\text { More than two years ago vs. Less than two years ago a }\end{array}$ & - & - & - & $1.59^{* *}(1.14-2.20)$ \\
\hline & $\begin{array}{l}\text { Main expense of the } \\
\text { household budget } \\
\text { Health expenses vs. other categories a }\end{array}$ & - & - & - & $2.02 * * *(1.36-2.99)$ \\
\hline & $\begin{array}{l}\text { Unemployed person in } \\
\text { the family } \\
\text { Yes vs. no } \\
\text { a }\end{array}$ & - & - & - & $1.50 * *(1.11-2.03)$ \\
\hline \multicolumn{2}{|r|}{ Corrected Akaike (AICc) } & 4482.8 & 4532.5 & 4585.0 & 4536.3 \\
\hline \multicolumn{2}{|r|}{ Precision } & 66.5 & 67.5 & 69.3 & 72.3 \\
\hline \multicolumn{2}{|r|}{ Area under ROC curve } & 0.50 & 0.54 & 0.59 & 0.64 \\
\hline
\end{tabular}


Model 1 builds on Model 0 by adding the score of satisfaction with area of residence and the score of neighborhood social capital as potential confounders. After adjustments, the association between mental health status and DI was no longer significant when comparing T1 with T3 (OR: 0.79, $p>0.05$ ) and remained significant in T2 vs. T3 (OR: $0.68, p<0.05$ ). The two variables included as perception of neighborhood characteristics were significant predictors of $\mathrm{MH}$ status. Individuals with lower neighborhood social capital (OR: $2.09, p<0.001)$ and lower satisfaction with area of residence (OR: $2.08, p<0.001$ ) had significantly higher risk of having poor $\mathrm{MH}$.

Model 2 added biological, socioeconomic, behavioral characteristics, and health status-age, gender, education, physical activity, smoking behavior, and hypertension-to the previous model. The results showed that the probability of having poor MH: increased with age (OR: 1.01, $p<0.01$ ); was higher for women (OR: women vs. men $=2.22, p<0.001$ ); was higher for lower educational levels, but not significantly (OR: $\leq 12$ years of education vs. $>12$ years of education $=1.20, p>0.05$ ); was higher for physically-inactive individuals (OR: inactivity vs. activity $=1.50, p<0.01$ ); increased in individuals with diagnosed hypertension (OR: diagnosed vs. not diagnosed $=1.50, p<0.01$ ); and did not significantly change with smoking behavior (OR: 1.00, $p>0.05)$. The contextual characteristics and perception of context characteristics maintained the same trend presented in Model 1 (the overlapping CI of these variables can be found in the comparison Model 1 and Model 2).

Model 3 further adjusted Model 2 by including economic and financial constraints: concerns with meeting one's daily expenses, whether one's household budget was mostly allocated to health, the presence of unemployed individuals in the family, and one's financial capacity. These variables were significantly associated with poor $\mathrm{MH}$; they particularly highlighted the high odds ratios of having poor $\mathrm{MH}$ found in individuals where the majority of their household budget was allocated to health expenses (OR: health expenses vs. other expenses $=2.02, p<0.001$ ) and individuals with difficulty paying daily expenses (OR: difficulty vs. saving capacity $=1.93, p<0.001$ ). The variables included in Model 2 did not change significantly after adjusting for economic and financial constraints, with the exception of diagnosed hypertension, which was no longer significant, although its trend was holding in the same direction.

\section{Discussion}

This is the first study in Portugal exploring the association between mental health and individual and neighborhood characteristics in the Lisbon region, after a period of economic crisis. In this region, one in three individuals reported poor $\mathrm{MH}(33 \%)$.

The results show that individuals living in deprived neighborhoods reporting lower social capital and lower satisfaction with their area of residence were associated with increased odds of poor $\mathrm{MH}$ $(p<0.05)$ in the final adjusted model (Model 3). These significant associations between a range of neighborhood characteristics (observed: DI and self-assessed: score of neighborhood social capital and score of satisfaction with area of residence) and poor mental health at the local level are consistent with previous studies on the mental health impacts of deprivation $[67,69]$, low social capital $[8,70]$, and low satisfaction with area of residence [71,72]. In areas of higher deprivation, the access to collective resources (including material and social resources, such as services, housing, job opportunities, and social supports) is often threatened $[57,73,74]$. The health and wellbeing of residents may be harmed by the limited access to quality amenities and services [73].

Furthermore, neighborhoods with low levels of social capital promote environments with fewer supports and buffers, enhancing the negative impacts of life events on $\mathrm{MH}[40,75]$. These residential environments lack the collective capacity to acquire and hold onto community resources (e.g., educational, health, housing resources) and do not promote individual behaviors intended to generate social support and safety nets [40].

The score of neighborhood social capital and the score of satisfaction with area of residence, constructed using the method presented, were applied in Portugal for the first time. Further research can validate the scales for the Portuguese population. 
The dimension of urban density assessed in this study (population density) was not significantly associated with $\mathrm{MH}$ in any model. In the literature, some urbanization processes (linked to high urban densities) have positive effects on mental health, provided, especially, by the higher proximity to public services and commercial facilities (e.g., healthcare, green spaces, social support facilities, public transport, food stores) [72,76] and by the consequent opportunity to move around and have an active social life [76]. However, other authors linked high densities with a higher risk of $\mathrm{MH}$ problems [77-80]. Denser urban areas can be also related to higher risk of mental health problems mainly due to built environment characteristics, influencing the sense of belonging and identity and family, and community relational support and networks [77,78,81].

Model 2 indicated that women and physically-inactive individuals had increased odds of poor MH $(p<0.05)$. Previous studies found the same pattern $[82,83]$. Women suffer more from mood disorders, anxiety, and phobias [83] and use more MH services [84], when compared with men. However, women are more likely to be treated for an $\mathrm{MH}$ problem because they are more likely to report symptoms and display signs of common mental illnesses [85]. Physical activity has been shown to intermediate the relationship between neighborhood characteristics and $\mathrm{MH}$ through the levels of security (crime rates) [86] or traffic and noise [87]. Scientific evidence showed that the relationship between neighborhood characteristics and $\mathrm{MH}$ is frequently indirect $[76,88]$. People are less likely to adopt healthier behaviors if the environment where they live fails to support their choices. A healthy neighborhood environment can promote opportunities for healthy behaviors and lifestyles, supporting social and environment interactions, which in turn may result in better mental health [88]. For instance, individuals may feel restrained from getting out (e.g., meet others, walking around, do exercise) if the immediate residential environment does not provide conditions to make them feel safe or to access green/blue and recreational areas [88,89].

This is an observational transversal study, and therefore, the existence of statistical associations between the characteristics of neighborhood environment and mental health should not be interpreted in terms of causality [89]. Lee et al. [90] mentioned that ecological or cross-sectional studies have limitations related to multiple confounding factors and long time lags between exposure to neighborhood elements and the manifestation of effects. Limitations linked to the use of cross-sectional data that may have impacts on our results are the inability to address the direction of the statistical association and to assess the influences of an individual's earlier life. Another information bias is related to the usage of self-reported information for both result and exposure variables, which can be influenced by memory bias or by social desirability [91].

Multiple dimensions associated with mental health were assessed; however, the area under ROC curve suggested that other important factors in this relationship were not included, namely due to constraints related to the availability of data at the neighborhood level, which are still to be addressed in future studies.

This study's results consistently showed that economic and financial constraints were significantly associated with poor $\mathrm{MH}$, when adjusted for the effects of neighborhood and individual factors, as shown in Model 3. The results, measured after the economic downturn, may have been influenced by this crisis context, considering the higher risks of poor MH related to: (i) the allocation of health expenses as the main expense of one's household budget; (ii) the households' financial situation of difficulty in paying one's expenses; (iii) the highest concern with meeting one's daily expenses; and (iv) the presence of unemployed individuals in the family.

Although a direct comparison with previous studies is limited, as our study did not measure the impact of the economic crisis, the results presented here are still comparable to a certain extent [92]. The international literature indicates that financial difficulties (e.g., lack of saving capacity or difficulty in paying one's expenses and debts), resulting from an economic and financial crisis given the increase of unemployment and/or cuts in public budgets, are associated with poor MH [93-96]. These mediating and moderating mechanisms related to economic shocks and fiscal austerity measures tend to increase 
the risk of mental health problems [97], contributing to higher socio-material vulnerability and inequity $[98,99]$.

In Portugal, several austerity measures focusing on reducing public expenditure were implemented via the Economic Adjustment Programme, which had negative consequences on population health and health inequalities [100-103]. The budget cuts in the health and social support sectors influenced the access to services, namely healthcare services, with a decrease in patient transportation support and an increase of user charges [47,104-106]. Moreover, several mental health consequences were observed during and after the Great Recession, as in the increase of: (i) the prevalence of mental disease [107], (ii) suicide [46,108], (iii) the use of the psychiatric services (inpatient units and outpatient clinics) [109], (iv) the demand for mental health emergency departments [110], (v) the under-treatment and discontinuity of care for individuals with mental health problems [111], and (vi) the use of psychotropic medications (anti-depressants and anxiolytics) [107].

The results obtained are important contributions to the current body of literature on the association between individual and neighborhood characteristics and mental health in the aftermath of the Great Recession. The promotion of mental health should include the integration of mental health into all policies and the multisectoral cooperation (e.g., urban planning and public health fields) [112] and should be present in several strategic documents on mental health (Worldwide: Mental Health Action Plan 2013-2020 [113]; Europe: European Framework for Action on Mental Health and Wellbeing 2016 [114]; and Portugal: Portuguese National Program For Mental Health 2017 [115]). The development of further research on strategic assessment of the impacts of environmental factors and neighborhood elements should be encouraged to better understand the mechanisms and the pathways of mental health.

\section{Conclusions}

The study provided evidence of the multidimensionality of the phenomenon of mental health in the Lisbon region after a context of crisis: the neighborhood characteristics played an important role regardless of one's individual characteristics. The findings obtained are important contributions that have increased our understanding of the impacts of neighborhood environment on $\mathrm{MH}$, considering the vulnerability and lack of opportunities that some urban characteristics, such as deprivation or social capital, can generate.

Thus, the improvement of MH is a shared multilevel challenge that can be addressed with an interdisciplinary approach, considering the complexity of the relationship between individuals and environments. The scientific knowledge resulting from this work contributes to better informing decision makers (e.g., professionals of urban planning and public health), and consequently, supporting intersectoral policies and interventions that prevent mental disorders and promote mental health, especially during periods of crisis.

Author Contributions: Conceptualization, A.L., P.S., and R.A.; data curation, A.L. and R.A.; formal analysis, A.L.; funding acquisition, P.S.; investigation, A.L., P.S. and R.A.; methodology, A.L., P.S., and R.A.; project administration, P.S.; resources, A.L., P.S. and R.A.; software, A.L. and R.A.; supervision, P.S. and C.N.; validation, P.S. and C.N.; visualization, A.L.; writing, original draft, A.L.; writing, review and editing, A.L., P.S., C.N. and R.A.

Funding: This research was funded by the investigation project PTDC/ATP-GEO/4101/2012, SMAILE, Mental Health-Evaluation of the Local and Economic Determinants, funded by the Portuguese Foundation for Science and Technology (FCT) and the European Regional Development Fund (FEDER), through the COMPETE-Operational Competitiveness Program. Adriana Loureiro is funded by FCT doctoral fellowship SFRH/BD/92369/2013 and by the CEGOT (Centre of Studies on Geography and Spatial Planning group) entitled "Cities, competitiveness, and well-being" (UID/GEO/04084/2013) through COMPETE 2020. Adriana Loureiro, Ricardo Almendra, and Paula Santana are members of CEGOT, which is supported by European Regional Development Funds through COMPETE 2020-Operational Programme "Competitiveness and Internationalization", under Grant POCI-01-0145FEDER-006891, and by National Funds through the FCT under Grant UID/GEO/04084/2013.

Acknowledgments: The authors would like to thank the SMAILE, Mental Health-Evaluation of the Local and Economic Determinants project team: (i) researchers, Carla Nunes, Graça Cardoso, José Caldas de Almeida, Maria Lucília Cardoso, and Pedro Pita Barros and (ii) consultants Benedetto Saraceno, João Ferrão, and Maria do Rosário Partidário. 
Conflicts of Interest: The authors declare no conflict of interest.

\section{Appendix A}

Table A1. Questions and respective response scales used to construct the score of satisfaction with area of residence.

\begin{tabular}{|c|c|c|c|c|c|}
\hline \multirow{2}{*}{$\begin{array}{c}\text { Questions (Are you Satisfied with:) } \\
\text { 1. Local Commerce? }\end{array}$} & \multicolumn{5}{|c|}{ Answer Options (Score Attributed to Each Option) } \\
\hline & Very satisfied (100) & Satisfied (66) & \multicolumn{2}{|c|}{ Not very satisfied (33) } & Not satisfied (0) \\
\hline 2. Outdoor leisure spaces? & Very satisfied (100) & Satisfied (66) & \multicolumn{2}{|c|}{ Not very satisfied (33) } & Not satisfied $(0)$ \\
\hline 3. Health services and facilities? & Very satisfied (100) & Satisfied (66) & \multicolumn{2}{|c|}{ Not very satisfied (33) } & Not satisfied (0) \\
\hline 4. Education services and facilities? & Very satisfied (100) & Satisfied (66) & \multicolumn{2}{|c|}{ Not very satisfied (33) } & Not satisfied (0) \\
\hline 5. Cultural services and facilities? & Very satisfied (100) & Satisfied (66) & \multicolumn{2}{|c|}{ Not very satisfied (33) } & Not satisfied (0) \\
\hline 6. Sports services and facilities? & Very satisfied (100) & Satisfied (66) & \multicolumn{2}{|c|}{ Not very satisfied (33) } & Not satisfied (0) \\
\hline 7. Public Transport? & Very satisfied (100) & Satisfied (66) & \multicolumn{2}{|c|}{ Not very satisfied (33) } & Not satisfied (0) \\
\hline 8. Parking? & Very satisfied (100) & Satisfied (66) & \multicolumn{2}{|c|}{ Not very satisfied (33) } & Not satisfied $(0)$ \\
\hline 9. Safety? & Very satisfied (100) & Satisfied (66) & \multicolumn{2}{|c|}{ Not very satisfied (33) } & Not satisfied (0) \\
\hline $\begin{array}{l}\text { 10. Cleaning (e.g., garbage collection, } \\
\text { urban cleaning)? }\end{array}$ & Very satisfied (100) & Satisfied (66) & \multicolumn{2}{|c|}{ Not very satisfied (33) } & Not satisfied (0) \\
\hline 11. Job offers? & Very satisfied (100) & Satisfied (66) & \multicolumn{2}{|c|}{ Not very satisfied (33) } & Not satisfied (0) \\
\hline $\begin{array}{l}\text { 12. Community Spaces (e.g., } \\
\text { associations, recreation centers, clubs)? }\end{array}$ & Very satisfied (100) & Satisfied (66) & \multicolumn{2}{|c|}{ Not very satisfied (33) } & Not satisfied (0) \\
\hline 13. Indoor noise levels (at home)? & Very good (100) & Good (75) & le (50) & Bad (25) & Very bad (0) \\
\hline 14. Outdoor noise levels? & Very good (100) & Good (75) & le $(50)$ & Bad (25) & Very bad $(0)$ \\
\hline 15. Outdoor air quality? & Very good (100) & Good (75) & le $(50)$ & $\operatorname{Bad}(25)$ & Very bad $(0)$ \\
\hline
\end{tabular}

Note: The satisfaction with residence score results from the arithmetic mean of the score of the questions. A minimum of 7 answers were required.

Table A2. Questions and respective response scales used to construct the score of neighborhood social capital.

\begin{tabular}{|c|c|c|c|c|c|c|c|c|}
\hline Questions & \multicolumn{8}{|c|}{$\begin{array}{c}\text { Answer Options } \\
\text { (Score Attributed to Each Option) }\end{array}$} \\
\hline 1. Do you live alone? & \multicolumn{4}{|c|}{ Yes (100) } & \multicolumn{4}{|c|}{ No $(0)$} \\
\hline 2. Do you like living in your parish? & $\begin{array}{l}\text { Like very } \\
\text { much }(100)\end{array}$ & \multicolumn{2}{|c|}{ Like (75) } & $\begin{array}{r}\text { Neither } \\
\text { dislik }\end{array}$ & $\begin{array}{l}\text { ke nor } \\
(50)\end{array}$ & \multicolumn{2}{|c|}{ Do not like (25) } & Dislike (0) \\
\hline $\begin{array}{l}\text { 3. How do you describe your } \\
\text { relationship with your neighbors in } \\
\text { the last year? }\end{array}$ & \multicolumn{2}{|c|}{$\begin{array}{l}\text { Much better or better than } \\
\text { usual (100) }\end{array}$} & \multicolumn{2}{|c|}{ Worse than usual (66) } & \multicolumn{2}{|c|}{$\begin{array}{l}\text { Much worse than } \\
\text { usual (33) }\end{array}$} & \multicolumn{2}{|c|}{$\begin{array}{l}\text { No relation with } \\
\text { neighbors }(0)\end{array}$} \\
\hline $\begin{array}{l}\text { 4. When in need of financial support } \\
\text { who do you ask? }\end{array}$ & Neighbors (100) & \multicolumn{2}{|c|}{ Family and/or friends (75) } & \multicolumn{2}{|c|}{ Bank (50) } & \multicolumn{2}{|c|}{$\begin{array}{l}\text { Social solidarity } \\
\text { institutions (25) }\end{array}$} & Nobody (0) \\
\hline $\begin{array}{l}\text { 5. When in need of emotional } \\
\text { support who do you ask? }\end{array}$ & Neighbors (100) & \multicolumn{2}{|c|}{ Family and/or friends (75) } & $\begin{array}{r}\text { Hea } \\
\text { professio }\end{array}$ & $\begin{array}{l}\text { th } \\
\text { als (50) }\end{array}$ & \multicolumn{2}{|c|}{$\begin{array}{l}\text { Social solidarity } \\
\text { institutions (25) }\end{array}$} & Nobody (0) \\
\hline $\begin{array}{l}\text { 6. Did you vote in the last } \\
\text { municipal elections? }\end{array}$ & \multicolumn{4}{|c|}{ Yes (100) } & & \multicolumn{2}{|c|}{ No $(0)$} & \\
\hline
\end{tabular}

Note: Satisfaction with residence score results from the arithmetic mean of the score of the questions. A minimum of 4 answers were required.

\section{References}

1. WHO. Depression and Other Common Mental Disorders. Global Health Estimates; WHO: Geneva, Switzerland, 2017.

2. Roth, G.A.; Abate, D.; Hassen Abate, K.; Abay, S.M.; Abbafati, C.; Abbasi, N.; Abbastabar, H.; Abd-Allah, F.; Abdela, J.; Abdelalim, A.; et al. Global, regional, and national age-sex-specific mortality for 282 causes of death in 195 countries and territories, 1980-2017: A systematic analysis for the Global Burden of Disease Study 2017. Lancet 2018, 10, 1736-1788. [CrossRef]

3. WHO. The World Health Report: 2001: Mental Health: New Understanding, New Hope; WHO: Geneva, Switzerland, 2001.

4. WHO. Mental Health: Strengthening Mental Health Promotion; Fact Sheet n⿳0220; WHO: Geneva, Switzerland, 2007; p. 2. 
5. Patel, V.; Lund, C.; Hatherill, S.; Plagerson, S.; Corrigall, J.; Funk, M.; Flisher, A.J. Mental disorders: Equity and social determinants. In Equity, Social Determinants and Public Health Programs; Blas, A., Kurup, A.S., Eds.; World Health Organization: Geneva, Switzerland, 2010; pp. 115-134.

6. Drukker, M.; van Os, J. Mediators of neighbourhood socioeconomic deprivation and quality of life. Soc. Psychiatry Psychiatr. Epidemiol. 2003, 38, 698-706. [CrossRef] [PubMed]

7. Kubzansky, L.D.; Subramanian, S.V.; Kawachi, I.; Fay, M.E.; Soobader, M.J.; Berkman, L.F. Neighborhood contextual influences on depressive symptoms in the elderly. Am. J. Epidemiol. 2005, 162, 253-260. [CrossRef] [PubMed]

8. Hamano, T.; Fujisawa, Y.; Ishida, Y.; Subramanian, S.V.; Kawachi, I.; Shiwaku, K. Social capital and mental health in Japan: A multilevel analysis. PLoS ONE 2010, 5. [CrossRef] [PubMed]

9. Rios, R.; Aiken, L.S.; Zautra, A.J. Neighborhood contexts and the mediating role of neighborhood social cohesion on health and psychological distress among hispanic and non-hispanic residents. Ann. Behav. Med. 2012, 43, 50-61. [CrossRef] [PubMed]

10. Skapinakis, P.; Lewis, G.; Araya, R.; Jones, K.; Williams, G. Mental health inequalities in Wales, UK: Multi-level investigation of the effect of area deprivation. Br. J. Psychiatry 2005, 186, 417-422. [CrossRef] [PubMed]

11. Fone, D.L.; Dunstan, F. Mental health, places and people: A multilevel analysis of economic inactivity and social deprivation. Health Place 2006, 12, 332-344. [CrossRef]

12. Araya, R.; Dunstan, F.; Playle, R.; Thomas, H.; Palmer, S.; Lewis, G. Perceptions of social capital and the built environment and mental health. Soc. Sci. Med. 2006, 62, 3072-3083. [CrossRef]

13. Sundquist, K.; Ahlen, H. Neighbourhood income and mental health: A multilevel follow-up study of psychiatric hospital admissions among 4.5 million women and men. Health Place 2006, 12, 594-602. [CrossRef]

14. Fone, D.; Dunstan, F.; Williams, G.; Lloyd, K.; Palmer, S. Places, people and mental health: A multilevel analysis of economic inactivity. Soc. Sci. Med. 2007, 64, 633-645. [CrossRef]

15. Fone, D.; Dunstan, F.; Lloyd, K.; Williams, G.; Watkins, J.; Palmer, S. Does social cohesion modify the association between area income deprivation and mental health? A multilevel analysis. Int. J. Epidemiol. 2007, 36, 338-345. [CrossRef] [PubMed]

16. Dupéré, V.; Perkins, D.D. Community types and mental health: A multilevel study of local environmental stress and coping. Am. J. Commun. Psychol. 2007, 39, 107-119. [CrossRef] [PubMed]

17. Lee, M.A. Neighborhood residential segregation and mental health: A multilevel analysis on Hispanic Americans in Chicago. Soc. Sci. Med. 2009, 68, 1975-1984. [CrossRef]

18. Macintyre, S.; Ellaway, A.; Cummins, S. Place effects on health: How can we conceptualise, operationalise and measure them? Soc. Sci. Med. 2002, 55, 125-139. [CrossRef]

19. Cummins, S.; Curtis, S.; Diez-Roux, A.V.; Macintyre, S. Understanding and representing "place" in health research: A relational approach. Soc. Sci. Med. 2007, 65, 1825-1838. [CrossRef] [PubMed]

20. Curtis, S. Space, Place and Mental Health; Ashgate: Surrey, UK, 2010; ISBN-13 9780754673316, ISBN-10 0754673316.

21. Macintyre, S.; Ellaway, A. Ecological approaches: Rediscovering the role of the physical and social environment. In Social Epidemiology; Oxford University Press: Oxford, UK, 2000; pp. 332-348.

22. WHO. Closing the Gap in a Generation; WHO: Geneva, Switzerland, 2008.

23. WHO. Review of Social Determinants and the Health Divide in the WHO European Region. Final Report; WHO: Geneva, Switzerland, 2013.

24. WHO. Calouste Gulbenkian Foundation. In Social Determinants of Mental Health; WHO: Geneva, Switzerland, 2014.

25. Santana, P.; Santos, R.; Nogueira, H. The link between local environment and obesity: A multilevel analysis in the Lisbon Metropolitan Area, Portugal. Soc. Sci. Med. 2009, 68, 601-609. [CrossRef] [PubMed]

26. Marmot, M. Fair Society, Healthy Lives: The Marmot Review: Strategic Review of Health Inequalities in England Post-2010, London: The Marmot Review. 2010. Available online: http://www.instituteofhealthequity.org/resources-reports/fair-society-healthy-lives-the-marmotreview/fair-society-healthy-lives-full-report-pdf.pdf (accessed on 11 January 2019).

27. Un Habitat; WHO. Global Report on Urban Health; WHO: Geneva, Switzerland, 2016.

28. Leventhal, T.; Brooks-Gunn, J. Moving to opportunity: An experimental study of neighborhood effects on mental health. Am. J. Public Health 2003, 93, 1576-1582. [CrossRef] 
29. Artazcoz, L.; Benach, J.; Borrell, C.; Cortès, I. Unemployment and mental health: Understanding the interactions among gender, family roles, and social class. Am. J. Public Health 2004, 94, 82-88. [CrossRef]

30. Almendra, R.; Loureiro, A.; Silva, G.; Vasconcelos, J.; Santana, P. Short-term impacts of air temperature on hospitalizations for mental disorders in Lisbon. Sci. Total Environ. 2019, 647, 127-133. [CrossRef]

31. Triguero-Mas, M.; Dadvand, P.; Cirach, M.; Martínez, D.; Medina, A.; Mompart, A.; Basagaña, X.; Gražulevičienè, R.; Nieuwenhuijsen, M.J. Natural outdoor environments and mental and physical health: Relationships and mechanisms. Environ. Int. 2015, 77, 35-41. [CrossRef]

32. Evans, G.W. The built environment and mental health. J. Urban. Health 2003, 80, 536-555. [CrossRef] [PubMed]

33. Miles, R.; Coutts, C.; Mohamadi, A. Neighborhood urban form, social environment, and depression. J. Urban. Health 2012, 89, 1-18. [CrossRef] [PubMed]

34. Evans, G.W.; Wells, N.M.; Moch, A. Housing and mental health: A review of the evidence and a methodological and conceptual critique. J. Soc. Issues 2003, 59, 475-500. [CrossRef]

35. Almedom, A.M. Social capital and mental health: An interdisciplinary review of primary evidence. Soc. Sci. Med. 2005, 61, 943-964. [CrossRef] [PubMed]

36. Todman, L.; Taylor, J.S.; McDowell, T.; Driscoll, M.; Cooper, D.; Kim, E. What are the Social Determinants of Mental Health? Available online: http://www.adler.edu/page/institutes/institute-on-social-exclusion/ projects/mhia/social-determinants-of-mental-health (accessed on 11 January 2019).

37. Ruhm, C.J. Healthy living in hard times. J. Health Econ. 2005, 24, 341-363. [CrossRef] [PubMed]

38. Stuckler, D.; Basu, S. The Body Economic: Why Austerity Kills; Basic Books: New York, NY, USA, 2013; ISBN 0465063977.

39. Trivedi, J.K.; Sareen, H.; Dhyani, M. Rapid urbanization-Its impact on mental health: A South Asian perspective. Indian J. Psychiatry 2008, 50, 161-165. [CrossRef]

40. Mckenzie, K. Urbanization, social capital and mental health. Glob. Soc. Policy 2008, 8, 359-377. [CrossRef]

41. Murphy, G.C.; Athanasou, J.A. The effect of unemployment on mental health. J. Occup. Organ. Psychol. 1999, 72, 83-99. [CrossRef]

42. Dooley, D. Unemployment, underemployment, and mental health: Conceptualizing employment status as a continuum. Am. J. Commun. Psychol. 2003, 32, 9-20. [CrossRef]

43. Zivin, K.; Paczkowski, M.; Galea, S. Economic downturns and population mental health: Research findings, gaps, challenges and priorities. Psychol. Med. 2011, 41, 1343-1348. [CrossRef]

44. Van Hal, G. The true cost of the economic crisis on psychological well-being: A review. Psychol. Res. Behav. Manag. 2015, 8, 17-25. [CrossRef] [PubMed]

45. Wahlbeck, K.; McDaid, D. Actions to alleviate the mental health impact of the economic crisis. World Psychiatry 2012, 11, 139-145. [CrossRef]

46. Santana, P.; Costa, C.; Cardoso, G.; Loureiro, A.; Ferrão, J. Suicide in Portugal: Spatial determinants in a context of economic crisis. Health Place 2015, 35, 85-94. [CrossRef] [PubMed]

47. Perelman, J.; Felix, S.; Santana, R. The Great Recession in Portugal: Impact on hospital care use. Health Policy 2015, 119, 307-315. [CrossRef] [PubMed]

48. Statistics Portugal. Available online: https://ine.pt/xportal/xmain?xpgid=ine_main\&xpid=INE (accessed on 11 January 2019).

49. Eurostat. Available online: https://ec.europa.eu/eurostat/data/database (accessed on 11 January 2019).

50. Meijer, M.; Bloomfield, K.; Engholm, G. Neighbourhoods matter too: The association between neighbourhood socioeconomic position, population density and breast, prostate and lung cancer incidence in Denmark between 2004 and 2008. J. Epidemiol. Commun. Health 2013, 67, 6-13. [CrossRef] [PubMed]

51. Statistics Portugal Censos 2011-Resultados Definitivos 2012. Available online: https://www.ine.pt/xportal/ xmain?xpid=INE\&xpgid=ine_indicadores\&indOcorrCod=0006510\&contexto=bd\&selTab=tab2 (accessed on 11 January 2019).

52. Stuckler, D.; Basu, S.; McKee, M.; Suhrcke, M. Responding to the economic crisis: A primer for public health professionals. J. Public Health 2010, 32, 298-306. [CrossRef]

53. Morais Nunes, A.; Cunha Ferreira, D.; Campos Fernandes, A. Financial crisis in Portugal: Effects in the health care sector. Int. J. Heal. Serv. 2019, 002073141882222. [CrossRef]

54. Ferreira, P.L.; Noronha Ferreira, L.; Nobre Pereira, L. Medidas sumário física e mental de estado de saúde para a população portuguesa. Rev. Port. Saude Publica 2012, 30, 163-171. [CrossRef] 
55. Ware, J.E., Jr.; Sherbourne, C.D. The MOS 36-Item Short-Form Health Survey (SF-36). I. Conceptual Framework and Item Selection. Med. Care 1992, 30, 473-483. [CrossRef]

56. Ware, J.E.; Snow, K.K.; Kosinski, M.; Gandek, B. SF-36 Health Survey Manual and Interpretation Guide; New England Medical Center: Boston, MA, USA, 1993; ISBN 1891810065.

57. Nogueira, H.G. Deprivation amplification and health promoting resources in the context of a poor country. Soc. Sci. Med. 2010, 70, 1391-1395. [CrossRef]

58. Almendra, R.; Santana, P.; Vasconcelos, J. Evidence of social deprivation on the spatial patterns of excess winter mortality. Int. J. Public Health 2017, 62, 849-856. [CrossRef] [PubMed]

59. Ribeiro, A.I.; Krainski, E.T.; Carvalho, M.S.; de Fátima de Pina, M. The influence of socioeconomic deprivation, access to healthcare and physical environment on old-age survival in Portugal. Geospat. Health 2017, 12, 581. [CrossRef] [PubMed]

60. Carstairs, V.; Morris, R. Deprivation and health in Scotland. Health Bull. 1990, 48, 162-175. [CrossRef]

61. Putnam, R.D. Bowling Alone; Simon \& Schuster: New York, NY, USA, 2000; ISBN 978-0-7432-0304-3.

62. Nogueira, H. Healthy communities: The challenge of social capital in the Lisbon Metropolitan Area. Health Place 2009, 15, 133-139. [CrossRef] [PubMed]

63. Santana, P.; Costa, C.; Freitas, Â.; Stefanik, I.; Quintal, C.; Bana e Costa, C.; Borrell, C.; Dimitroulopoulou, S.; Lopes Ferreira, P.; Krafft, T.; et al. Atlas of Population Health in European Union Regions; Santana, P., Ed.; Imprensa da Universidade de Coimbra: Coimbra, Portugal, 2017; ISBN 978-989-26-1462-5.

64. Braveman, P. What are health disparities and health equity? We need to be clear. Public Health Rep. 2014, 129, 5-8. [CrossRef] [PubMed]

65. Ballas, D.; Lupton, R.; Kavroudakis, D.; Hennig, B.; Yiagopoulou, V.; Dale, R.; Dorling, D. Mind the Gap_Education Inequality Across EU Regions; European Union: Brussels, Belgium, 2012.

66. WHO. Environment and Health Risks: A Review of Social Inequalities; WHO: Copenhagen, Denmark, 2010.

67. Chum, A.; O'Campo, P. Cross-sectional associations between residential environmental exposures and cardiovascular diseases. BMC Public Health 2015, 15, 438. [CrossRef] [PubMed]

68. Subramanian, S.V.; Kawachi, I.; Kennedy, B.P. Does the state you live in make a difference? Multilevel analysis of self-rated health in the US. Soc. Sci. Med. 2001, 53, 9-19. [CrossRef]

69. Chung, R.Y.-N.; Chung, G.K.-K.; Gordon, D.; Wong, S.Y.-S.; Chan, D.; Lau, M.K.-W.; Tang, V.M.-Y.; Wong, H. Deprivation is associated with worse physical and mental health beyond income poverty: A population-based household survey among Chinese adults. Qual. Life Res. 2018, 27, 2127-2135. [CrossRef]

70. Shahidul Islam, M.; Shafiul Alam, M. Social capital and mental health: Results from a cross-sectional study in Bangladesh. Asian Soc. Sci. 2013, 10, 118. [CrossRef]

71. Bond, L.; Kearns, A.; Mason, P.; Tannahill, C.; Egan, M.; Whitely, E. Exploring the relationships between housing, neighbourhoods and mental wellbeing for residents of deprived areas. BMC Public Health 2012, 12, 1-14. [CrossRef]

72. Dalgard, O.S.; Tambs, K. Urban environment and mental health. A longitudinal study. Br. J. Psychiatry 1997. [CrossRef] [PubMed]

73. Stafford, M.; Marmot, M. Neighbourhood deprivation and health: Does it affect us all equally? Int. J. Epidemiol. 2003, 32, 357-366. [CrossRef] [PubMed]

74. WHO. A Conceptual Framework for Action on the Social Determinants of Health; WHO: Geneva, Switzerland, 2010.

75. Bassett, E.; Moore, S. Mental health and social capital: Social capital as a promising initiative to improving the mental health of communities. In Current Topics in Public Health; InTech: London, UK, 2013.

76. Melis, G.; Gelormino, E.; Marra, G.; Ferracin, E.; Costa, G. The effects of the urban built environment on mental health: A cohort study in a large northern Italian city. Int. J. Environ. Res. Public Health 2015, 12, 14898-14915. [CrossRef] [PubMed]

77. Sundquist, K.; Frank, G.; Sundquist, J. Urbanisation and incidence of psychosis and depression: Follow-up study of 4.4 million women and men in Sweden. Br. J. Psychiatry 2004, 184, 293-298. [CrossRef] [PubMed]

78. Kaymaz, N.; Krabbendam, L.; Graaf, R.; Nolen, W.; Have, M.; van Os, J. Evidence that the urban environment specifically impacts on the psychotic but not the affective dimension of bipolar disorder. Soc. Psychiatry Psychiatr. Epidemiol. 2006, 41, 679-685. [CrossRef]

79. Weich, S.; Twigg, L.; Lewis, G. Rural/non-rural differences in rates of common mental disorders in Britain: Prospective multilevel cohort study. Br. J. Psychiatry 2006, 188, 51-57. [CrossRef] 
80. Peen, J.; Dekker, J.; Schoevers, R.; Have, M.; de Graaf, R.; Beekman, A. Is the prevalence of psychiatric disorders associated with urbanization? Soc. Psychiatry Psychiatr. Epidemiol. 2007, 42, 984-989. [CrossRef]

81. Paykel, E.; Abbott, R.; Jenkins, R.; Brugha, T.; Meltzer, H. Urban-rural mental health differences in Great Britain: Findings from the National Morbidity Survey. Int. Rev. Psychiatry 2003, 30, 269-280. [CrossRef]

82. Simon, R.W. Revisiting the Relationships among Gender, Marital Status, and Mental Health. Am. J. Sociol. 2002, 107, 1065-1096. [CrossRef]

83. Eaton, N.R.; Keyes, K.M.; Krueger, R.F.; Balsis, S.; Skodol, A.E.; Markon, K.E.; Grant, B.F.; Hasin, D.S. An invariant dimensional liability model of gender differences in mental disorder prevalence: Evidence from a national sample. J. Abnorm. Psychol. 2012, 121, 282-288. [CrossRef]

84. Van De Velde, S.; Boyd, A.; Masfety, V.K. The Gender Perspective of Mental Health in Europe. In The Burden of Mental Health Disorders in Europe; 2012.

85. Brown, J.; Learmonth, A.; Mackereth, C. Promoting Public Mental Health and Well-Being: Principles into Practice; Jessica Kingsley Publishers: London, UK, 2015.

86. Meyer, O.L.; Castro-Schilo, L.; Aguilar-Gaxiola, S. Determinants of mental health and self-rated health: A model of socioeconomic status, neighborhood safety, and physical activity. Am. J. Public Health 2014, 104, 1734-1741. [CrossRef] [PubMed]

87. Dratva, J.; Zemp, E.; Dietrich, D.F.; Bridevaux, P.O.; Rochat, T.; Schindler, C.; Gerbase, M.W. Impact of road traffic noise annoyance on health-related quality of life: Results from a population-based study. Qual. Life Res. 2010, 19, 37-46. [CrossRef] [PubMed]

88. Burton, L. Mental Well-being and the Influence of Place. In The Routledge Handbook of Planning for Health and Well-Being: Shaping a Sustainable and Healthy Future; Barton, H., Thompson, S., Burgess, S., Grant, M., Eds.; Taylor \& Francis: Oxford, UK, 2015; p. 617.

89. Jokela, M. Are neighborhood health associations causal? A 10-year prospective cohort study with repeated measurements. Am. J. Epidemiol. 2014, 180, 776-784. [CrossRef] [PubMed]

90. Lee, A.C.; Maheswaran, R. The health benefits of urban green spaces: A review of the evidence. J. Public Health 2011, 33, 212-222. [CrossRef] [PubMed]

91. Dunstan, F.; Fone, D.L.; Glickman, M.; Palmer, S. Objectively measured residential environment and self-reported health: A multilevel analysis of UK census data. PLoS ONE 2013, 8, e69045. [CrossRef] [PubMed]

92. Almendra, R.; Perelman, J.; Vasconcelos, J.; Santana, P. Excess winter mortality and morbidity before, during, and after the Great Recession: The Portuguese case. Int. J. Biometeorol. 2019, 63, 873-883. [CrossRef]

93. Lee, S.; Guo, W.J.; Tsang, A.; Mak, A.D.P.; Wu, J.; Ng, K.L.; Kwok, K. Evidence for the 2008 economic crisis exacerbating depression in Hong Kong. J. Affect. Disord. 2010, 126, 125-133. [CrossRef]

94. Brown, S.; Taylor, K.; Wheatley Price, S. Debt and distress: Evaluating the psychological cost of credit. J. Econ. Psychol. 2005. [CrossRef]

95. Drydakis, N. The effect of unemployment on self-reported health and mental health in Greece from 2008 to 2013: A longitudinal study before and during the financial crisis. Soc. Sci. Med. 2015, 26, 642-663. [CrossRef]

96. Gili, M.; Roca, M.; Basu, S.; McKee, M.; Stuckler, D. The mental health risks of economic crisis in Spain: Evidence from primary care centres, 2006 and 2010. Eur. J. Public Health 2013, 23, 103-108. [CrossRef]

97. Friedman, J.; Thomas, D. Psychological health before, during, and after an economic crisis: Results from Indonesia, 1993-2000. World Bank Econ. Rev. 2009, 23, 57-76. [CrossRef] [PubMed]

98. Stuckler, D.; Basu, S.; Suhrcke, M.; Coutts, A.; McKee, M. The public health effect of economic crises and alternative policy responses in Europe: An empirical analysis. Lancet 2009, 374, 315-323. [CrossRef]

99. Veenhoven, R.; Hagenaars, A. Did the Crisis Really Hurt? Effects of the 1980-1982 Economic Recession on Satisfaction, Mental Health and Mortality; Erasmus Universiteit Rotterdam: Rotterdam, The Netherlands, 1989.

100. Nogueira, H. What is happening to health in the economic downturn? A view of the Lisbon Metropolitan Area, Portugal. Ann. Hum. Biol. 2016, 43, 164-168. [CrossRef] [PubMed]

101. Doetsch, J.; Pilot, E.; Santana, P.; Krafft, T. Potential barriers in healthcare access of the elderly population influenced by the economic crisis and the troika agreement: A qualitative case study in Lisbon, Portugal. Int. J. Equity Health 2017, 16, 184. [CrossRef] [PubMed]

102. Santos, J.C.; Cutcliffe, J. The recent global socioeconomic crisis and its effects on mental health in Portugal. Ment. Health Nurs. 2013, 33, 33-35. [CrossRef] 
103. Antunes, A.; Frasquilho, D.; Azeredo-Lopes, S.; Silva, M.; Cardoso, G.; Caldas-de-Almeida, J.M. Changes in socioeconomic position among individuals with mental disorders during the economic recession in Portugal: A follow-up of the National Mental Health Survey. Epidemiol. Psychiatr. Sci. 2018, 1-6. [CrossRef] [PubMed]

104. Sakellarides, C.; Castelo-Branco, L.; Barbosa, P.; Azevedo, H. The Impact of the Financial Crisis on the Health System and Health in Portugal; WHO: Copenhagen, Denmark, 2014.

105. Dubois, H.; Anderson, R. Impacts of the Crisis on access to Healthcare Services in the EU: Country Report Portugal; Cornell University: Dublin, Ireland, 2013.

106. Russo, G.; Rego, I.; Perelman, J.; Barros, P.P. A tale of loss of privilege, resilience and change: The impact of the economic crisis on physicians and medical services in Portugal. Health Policy 2016, 120, 1079-1086. [CrossRef]

107. Silva, M.; Antunes, A.; Frasquilho, D.; Cardoso, G.; Caldas-de-Almeida, J.M. The impact of the economic crisis on the use of psychotropic medication in Portugal: Preliminary results of the national mental health survey follow-up. Eur. Psychiatry 2017, 41, S579. [CrossRef]

108. Loureiro, A.; Almendra, R.; Costa, C.; Santana, P. Mortalidade por suicídio nos municípios de Portugal continental: Evolução espácio-temporal entre 1980 e 2015. Acta Med. Port. 2018, 31, 38-44. [CrossRef]

109. Cardoso, G.; Loureiro, A.; Mateus, P.; Silva, M.; Santana, P.; Caldas de Almeida, J. Utilização de Serviços de Saúde Mental em Portugal em tempos de crise económica. In Território e Saúde Mental em Tempos de Crise; Santana, P., Ed.; Imprensa da Universidade de Coimbra: Coimbra, Portugal, 2015; pp. 75-92, ISBN 978-989-26-1105-1.

110. Vaz, S.; Ramos, P.; Felgueiras, J. A procura pelos cuidados de urgência de saúde mental em Portugal em tempos de crise. In Território e Saúde Mental em Tempos de Crise; Santana, P., Ed.; Imprensa da Universidade de Coimbra: Coimbra, Portugal, 2015; pp. 93-103, ISBN 9789892611051.

111. Silva, M.; Antunes, A.; Frasquilho, D.; Cardoso, G.; Caldas-de-Almeida, J.M. Services utilization for mental health problems in Portugal during the economic crisis: Preliminary results of the national mental health survey follow-up. Eur. Psychiatry 2017, 41, S579. [CrossRef]

112. Botezat, I.; Campion, J.; Garcia-Cubillana, P.; Guðmundsdóttir, D.; Halliday, W.; Henderson, N.; Holte, A.; Heitor Santos, M.J.; Japing, K.; Kearney, N.; et al. Mental Health in All Policies. Situation Analysis and Recommendations for Action; European Union, Joint Action on Mental Health and Well-being: Brussels, Belgium, 2017.

113. WHO. Mental Health Action Plan 2013-2020; WHO: Geneva, Switzerland, 2013.

114. European Union. European Framework for Action on Mental Health and Wellbeing; EU JA-MHW; European Union: Brussels, Belgium, 2016.

115. SNS. Programa Nacional para a Saúde Mental 2017; SNS: Lisbon, Portugal, 2017. 